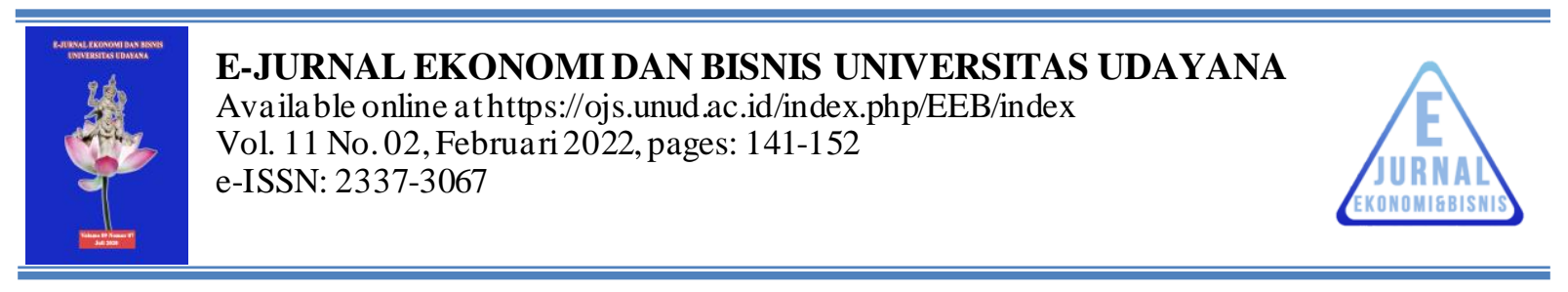

\title{
STRATEGI PENETAPAN BEA KELUAR EKSPOR RUMPUT LAUT SEBAGAI UPAYA OPTIMALISASI INDUSTRI KARAGINAN DALAM NEGERI
}

\author{
Mas Ayu Faradiah ${ }^{1}$ Lies Maria Hamzah $^{2}$ Saimul $^{3}$
}

Article history:

Submitted: 25 Juni 2021

Revised: 25 Juli 2021

Accepted: 13 Agustus 2021

Keywords:

Export Tax;

Gravity Models;

Carageenan Industry;

\section{Kata Kunci:}

Bea Keluar;

Model Gra vitasi;

Industri Karaginan;

\section{Koresponding:}

Universitas Lampung,

Lampung, Indonesia

Email:

masayufaradiah@gmail.com

\section{Abstract}

The best producers of seaweed commodities mostly come from Asia, one of which is Indonesia. The continued increase in the export volume of primary seaweed has made the domestic carrageenan processing industryexperience difficulties with raw materials. So this study was conducted tofind out what factors influence the demand for seaweed exports from Indonesia to 10 destination countries, namely China, Philippines, Vietnam, Republic of Korea, Chile, United Kingdom, USA, Hong Kong, Germany and France with a period of 2015 - 2019. From the results of the analysis using panel data with the gravity model, it is known that the exportprice of Indonesian seaweed and economic distance have a negative and significant effecton the export volume of seaweed. Meanwhile, GDP has a positive and signific ant effect. As an effort to reduce exports of dried seaweed, from the analysis of price elasticity, it is known that the determination of an export duty policy of $18 \%$ can reduce exports effectively. As well as the need for extension prog rams, mentoring and partnerships for seaweed farmers and seaweed processing industry players to be able to optimize output that can compete in the internationalmarket.

\begin{tabular}{|c|}
\hline Abstrak \\
\hline 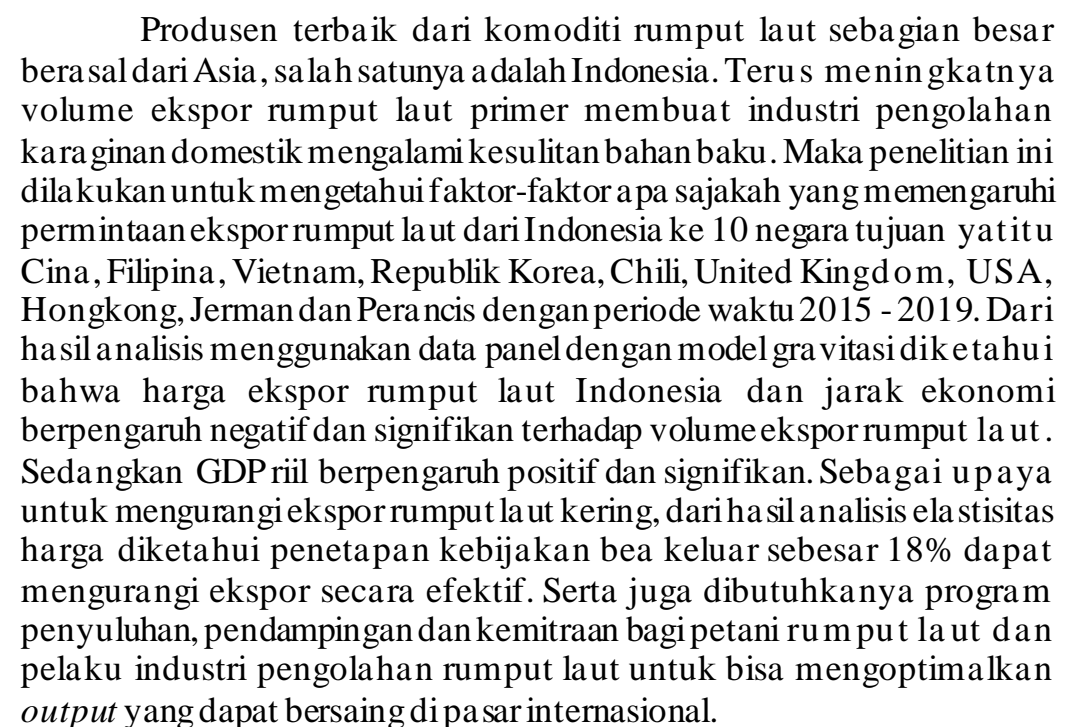 \\
\hline
\end{tabular}

Universitas Lampung, Lampung, Indonesia ${ }^{2,3}$ 


\section{PENDAHULUAN}

Salah satu negara maritim yang terkenal memiliki sumber daya alam yang melimpah adalah Indonesia. Dimana sektor perikanan menjadi salah satu komoditi unggulan ekspor dari Indonesia yang sudah tidak diragukan lagi di pasar internasional. Di masa kini ataupun masa yang akan datang rumput laut dapat menjadi tumpuan bagi masayarakat pesisir serta pelaku industrinya (Zainol Arifin, 2013). Dari sekian banyak produk perikanan salah satu komoditi ekspor unggulan dari Indonesia adalah rumput laut. Indonesia merupakan produsen terbesar ke-2 terbesar rumput laut dunia (FAO, 2018). Salah satu sumber devisa negara adalah dari ekspor rumput laut di Indonesia dimana rata-rata produksi rumput laut kering mencapai 16 ton per Ha (Efendi, 2017). Memiliki nilai ekonomi yang tinggi ( $h i g h$ value commodity) merupakan salah satu dari keunggulan yang dimiliki komoditi rumput laut. Komoditi rumput laut memiliki pohon industri yang lengkap dan sprektum penggunaanya juga luas. Teknologi budidayarumput laut yang terbilang mudah menyebabkan banyak industri mengembangkan rumput laut sehingga dapat menyerap banyak tenaga kerja. Budidaya rumput laut memiliki masa tanam yang pendek yaitu hanya sekitar 45 hari, sehingga biaya per produksinya relative sangat murah. Tidak Industri rumput laut merupakan program yang memiliki prospek yang sangat baik untuk dikembangkan. Pentingnya peran budidaya rumput laut bukan hanya dalam hal pemenuhan pangan dan kebutuhn pasar teteapi juga dapat meningkatkan kesejahteraan para petaninya (Ika Fatmawati \& Didik Wahyudi, 2015).

Rumput laut merupakan komoditi yang memiliki potensi dalam meningkatkan ekspor produk perikanan di Indonesia. Selain banyak negara melakukan impor rumput laut sebagai bahan makanan, rumput laut juga banyak digunakan sebagai bahan baku industri (KKP, 2021). Penggunaan rumput laut sebagai bahan baku makanan dan sebagai bahan baku pembuatan obat-obatan (anticoagulant, antibiotics, antimehmetes, antihypertensive agent, pengurang kolestrol, dilatory agent, dan insektisida) merupakan manfaat unggulan dari rumput laut yang membuat rumput laut memiliki nilai jual yang tinggi (Sukapto \& Bagus Made Arthaya, 2014). Seiringnya waktu produk olahan rumput laut memiliki perkembangan yang cukup pesat. Banyak produk yang dapat diolah dari produk turunan rumput laut seperti kertas, bahan kosmetik, cat, pasta gigi, bahan laboratorium dan lainya (Indriani dan Sumiarsih, 1999).Selama 5 (lima) tahun terakhir permintaan ekspor komoditi rumput laut Indonesia didominasi oleh 10 negara pengekspor utama yaitu China, Chili, Vietman, Filipina, Hongkong, Perancis, Spanyol, Jepang dan Denmark. Terlihat dari gambar di bawah ini bahwa permintaan ekspor rumput laut Indonesia mengalami peningkatan setiap tahunya secara umum baik secara volume maupun secara nilai. Hal tersebut membuktikan bahwa rumput laut memiliki potensi lebih jauh untuk dikembangkan menjadi produk unggulan ekspor disektor perikanan.

Menurut Satar \& Kurnia Nurhakim (2015), kegiatan transaksi menjual barang atau jasa dari daerah pabean dengan mematuhi peraturan dan perundang-undangan yang berlaku merupakan kegiatan yang biasa disebut dengan kegiatan ekspor. Meskipun ekspor rumput laut memiliki tren yang meningkat setiap tahunya, tetapi perlu diketahui bahwa yang diekspor adalah produk primer. Dimana produk primer memiliki harga yang relatif lebih rendah disbandingkan jika komoditi yang diekspor telah memiliki nilai tambah. Dalam upaya meningkatkan nilai tambah pada komoditi rumput laut, perlu dikembangkanya struktur industri end product serta produk formulasi. Berdasarkan UndangUndang Nomor 31 Tahun 2004 juncto Undang-Undang Nomor Tahun 2009 mengenai kebijakan peningkatan nilai tambah yang diharapkan dapat menjadi landasan hukum yang kuat untuk Indonesia untuk dapat memaksimalkan upaya dalam meningkatkan nilai tambah pada komoditi rumput laut. Kebijakan mengenai Industri Nasional juga diatur dalam Peraturan Presiden Republik Indonesia Nomor 28 Tahun 2008 (Lestari Agusalim, 2014).

Strategi Penetapan Bea Keluar Ekspor Rumput Laut Sebagai Upaya Optimalisasi Industri Karaginan Dalam 


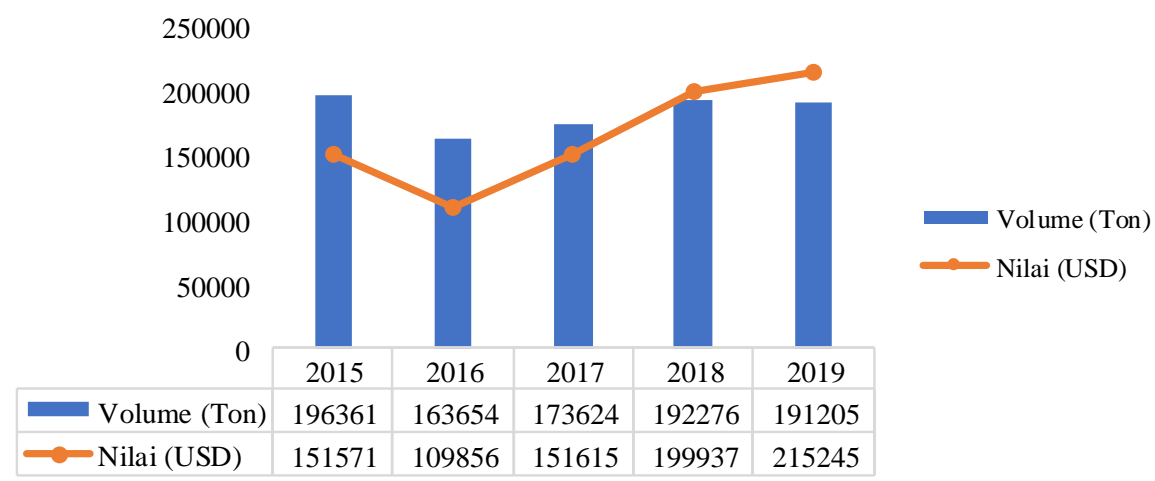

Sumber: BPS, 2020

\section{Gambar 1.}

Data Ekspor Rumput Laut ke Negara Tujuan dalam Volume (Ton) dan Nilai (USD)

Dengan begitu maka Indonesia dapat mengurangi ekspor rumput laut kering ke luar negeri, sehingga industri pengolahan domestik dapat memaksimalkan produksinya karena bahan baku yang tercukupi. Rumput laut kering sebagai bahan baku yang belum diberi nilai tambah hanya memiliki nilai jual sebesar Rp. 7000 per kilogram. Untuk rumput laut yang sudah diberi nilai tambah dalam bentuk chip memiliki nilai jual sebesar Rp. 60,000 per kilogram, semi refined carrageenan memiliki nilai jual sebesar Rp. 80,000 per kilogram, refined carrageenan memiliki nilai jual Rp. 200,000 per kilogram untuk food grade dan Rp. 180,000 per kilogram pada industrial grade. Dengan tingkat harga yang rendah pada rumput laut kering sebagai bahan baku, tidak heran banyak negara lain yang memutuskan untuk membeli bahan baku rumput laut kering dari Indonesia. Harga jual yang rendah dari rumput laut kering menyebabkan peningkatan permintaan ekspor secara besar-besaran dengan harga yang relatif rendah sehingga keuntungan yang didapat oleh petani rumput laut juga tidak maksimal. Hal tersebut tentu tidak hanya merugikan petani terutama dalam kondisi pandemi seperti ini. Indsutri pengolahan rumput laut domestik juga mengalami kendala yaitu kesulitan mendapatkan bahan baku sehingga produksi rumput olahan dalam negeri mengalami penurunan produksi. Dibutuhkan kebijakan negara yang tepat dari suatu negara untuk tidak hanya dapat memperluas pasar internasional tetapi juga melindungi pelaku usaha domestik (Maswadi, 2012).

Menurut (Denantica, 2012), diketahui bahwa faktor-faktor yang memengaruhi ekspor ru mput laut Indonesia adalah harga ekspor, produksi rumput laut nasional, dummy revitalisasi, GDP negara pengimpor, volume ekspor dan nilai tukar riil. Dimana produksi rumput laut nasional,GDP negara pengimpor, dummy revitalisasi dan volume ekspor berpengaruh positif dan signifikan. Sedangkan untuk variabel harga ekspor rumput laut dan nilai tukar riil memiliki pengaruh yang negatif dan signifikan. Diperlukanya kebijakan yang tepat dari pemerintah untuk meningkatkan daya saing ekspor Meningkatnya ekspor rumput laut olahan, dari hasil penelitian (Khaldun, 2017) diketahui bahwa dengan konsep Blue Economy dimana kebijakan revitalisasi dari sektor hulu hingga industrialisasi dan adanya pemberlakuan standarisasi produk rumput laut dari Standar Nasional Indonesia (SNI) dapat mendorong potensial yang dimiliki sektor perikanan terutama komoditi rumput laut. Menurut penelitian (Eni Kusumawati, 2019), pajak ekspor berpengaruh negatif dan signifikan sedangkan untuk harga ekspor signifikan dan memiliki pegaruh positif.

Strategi Penetapan Bea Keluar Ekspor Rumput LautSebagai Upaya Optimalisasi Industri Karaginan Dalam 


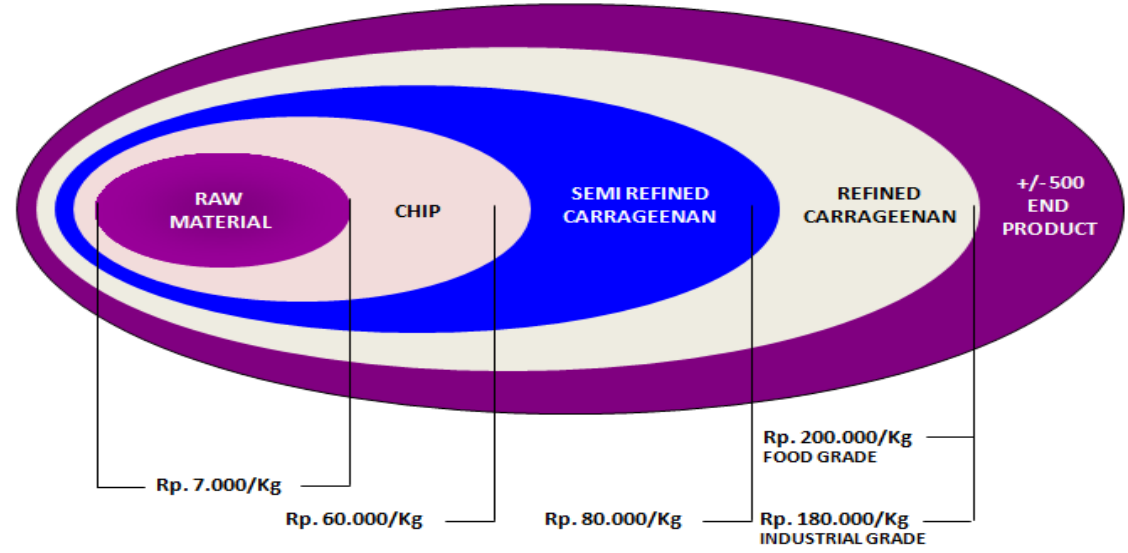

Sumber: DKP, 2019

Gambar 2.

Tingkat Harga Rumput Laut dari Mulai Bahan Baku Hingga End Product

Komoditi rumput laut memiliki potensi yang besar untuk ditingkatkan terutama bagi para petaninya sendiri maupun para pemilik industri pengolahan rumput laut. Menurut (A. Muhammad Yushan Patawari \& Nyoman Suarsana, 2019) untuk dapat menggali potensi komoditi rumput laut dari segi ekonomi, dibutuhkan peningkatan pengetahuan para petani rumput laut mengenai bagaimana melakukan teknik budidaya dengan efektif, menerapkan pola kemitraan bagi para petani rumput laut untuk menjaga kestabilan harga jual dan bantuan usaha yang memadai bagi pelaku industri pengolahan rumput Indonesia.

Untuk dapat meningkatkan peluang dari komoditi rumput laut Indonesia perlu dilakukan pengembangan terkait permasalahan keterbatasan lahan budidaya, ketersediaan bahan baku untuk industri pengolahan rumput laut dan kualitas dari produk rumput laut olahan Indonesia, maka diperlukan pengembangan lebih lanjut pada industri rumput laut olahan (ATC, SRC dan RC) pada skala usaha tradisional yang dikembangkan menjadi skala industri secara bertahap (Hikmah, 2021). Untuk meningkatkan perekonomian para petani dan pelaku industri, dibutuhkan program pemerintah dalam memberikan pendampingan mengenai cara pengolahan rumput laut (Farhanah Wahyu, 2011). Tidak hanya perlu didampingi, para petani rumput laut dan pelaku industri karaginan juga memerlukan bantuan program dan dari pemerintah dan pendampingan sampai dengan sistem pemasaran (Sudiarta, 2017).

Tanpa adanya value added dalam suatu komoditi yang menyebabkan industri dalam negeri kekurangan bahan baku adalah suatu fenomena yang menarik untuk dilakukan penelitian lebih lanjut. Hasil penelitian yang dilakukan mengenai faktor-faktor yang memengaruhi volume ekspor kelapa sawit menunjukkan harga domestik dan produksi sawit berpengaruh positif dan signifikan terhadap volume ekspor, sedangkan harga dunia dan nilai tukar berpengaruh negatif serta signifikan terhadap volume ekspor kelapa sawit sehingga dibutuhkanya pengembangan dalam industri hilir untuk memaksimalkan produksi sawit dan nilai tambah (Faisal \& Akmal Huda Nasution, 2015). Menurut Rachman \& Adang Agustian (2015) salah satu sumber Pungutan Peneriman Bukan Pajak (PNBP) salah satunya berasal dari pungutan pajak ekspor dengan Harga Patokan Ekspor (HPE). Dimana hasil penelitianya menunjukan bahwa dengan adanya pajak ekspor dapat menurunkan ekspor komoidit kelapa sawit tanpa nilai tambah dan meningkatkan keuntungan bagi konsumen CPO (industri

Strategi Penetapan Bea Keluar Ekspor Rumput Laut Sebagai Upaya Optimalisasi Industri Karaginan Dalam 
pengolahan). Serta untuk meningkatkan daya saing komoditas kelapa sawit diperlukan budidaya usahatani mulai dari dilakukanya peningkatan produksi hingga ekspor.

Dari penelitian terdahulu yang sudah dilakukan belum ada penelitian yang melakukan penelitian memasukan variabel jarak ekonomi dengan gravity model sebagai variabel untuk mengetahui faktor-faktor apa sajakah yang memengaruhi volume ekspor suatu komoditi. Tujuan dari penelitian ini untuk melihat faktor-faktor yang memengaruhi ekspor rumput laut dari sisi permintaan dengan gravity model, untuk lebih lanjut melihat bagaimana hubungan antara harga ekspor rumput laut, jarak ekonomi dan GDP (Gross Domestic Bruto) terhadap volume ekspor rumput laut, serta untuk mengetahui berapa besaran bea keluar yang dapat ditetapkan dalam kebijakan pengurangan ekspor rumput laut primer. Dimana dalam penellitian sebelumnya belum ada yang meneliti mengenai kebijakan penetapan bea keluar yang harus ditetapkan dalam mengurangi ekspor produk primer rumput laut. Dari tujuan penelitian tersebut yang didasarkan oleh beberapa penelitian terdahulu maka dapat ditarik hipotesis bahwa harga ekspor dan jarak ekonomi berpengaruh negatif terhadap volume ekspor, sementara GDP (Gross Domestic Product) berpengaruh positif terhadap volume ekspor rumput laut. Untuk mengetahui besaran penetapan bea keluar rumput laut akan dianggap efektif untuk mengurangi jumlah ekspor rumput laut primer dan hasilnya akan diketahui dengan analisis elastisitas harga rumput laut.

\section{METODE PENELITIAN}

Penelitian ini menggunakan pendekatan kuantitatif yang menganalisis pengaruh jarak ekonomi, harga ekspor rumput laut dan GDP (Gross Domestic Product) sebagai variabel bebas atau independent terhadap volume ekspor rumput laut ke negara tujuan sebagai variabel terikat atau dependent. Penelitian ini menggunakan jenis data panel dimana dalam data ini digabungkan jenis data time series dan cross section dengan model gravitasi. Model gravitasi adalah alat analisis yang cocok untuk penelitian terkait analisis dampak dari kebijakan pemerintah pada sektor perdagangan (Shepherd, 2013).

Periode waktu analisis pada penelitian ini dimulai dari tahun 2015 hingga 2019. Penelitian ini dilakukan dalam priode waktu 5 (lima) tahun terakhir dimana data menunjukan bahwa terjadinya peningkatan komoditi ekspor rumput laut primer dimana rata-rata 5 (lima) tahun terakhir mencapai 165 ribu ton yang mengakibatkan rendahnya tingkat harga ekspor di pasar internasional dan menyebabkan industri pengolahan mengalami kesulitan bahan baku (KKP, 2021) Penelitian ini menganalisis 10 besar negara tujuan ekspor rumput laut dari Indonesia yang terdiri dari Cina, Filipina, Vietnam, Republik Korea, Cili, United Kingdom, USA, Hongkong, Jerman dan Perancis, ke 10 negara ini merupakan negara-negara yang secara konsisten menjadi pengimpor rumput laut primer dari Indonesia dalam jumlah yang besar selama 5 (lima) tahun terakhir. Fokus data yang digunakan dalam penelitian ini adalah produksi rumput laut domestik, harga ekspor rumput laut kering, jarak ekonomi dan GDP riil negara tujuan ekspor. Sumber data yang digunakan dalam penelitian ini diperoleh dari BPS, World Bank dan UNCOMTRADE.

Dari model dasar gravity model, dilakukan transformasi model kedalam bentuk ln (logaritma natural). Model yang digunakan dalam penelitian ini merujuk kepada penelitian sebelumnya yang sudah dilakukan modifikasi dengan menambahkan variabel jarak (Denantica, 2012) adalah sebagai berikut:

$$
\text { LnVEit }=\beta 0+\operatorname{Ln} \beta 1 E P i t+\operatorname{Ln} \beta 3 \text { GDPit }+\operatorname{Ln} \beta 4 \text { DISTit }+ \text { eit }
$$

Strategi Penetapan Bea Keluar Ekspor Rumput Laut Sebagai Upaya Optimalisasi Industri Karaginan Dalam 


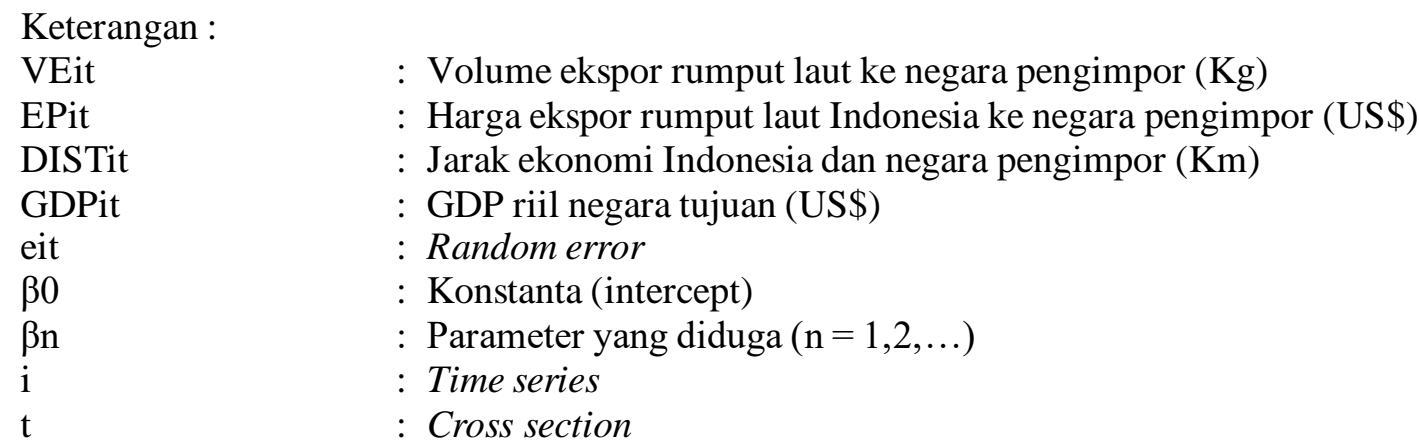

\section{HASIL DAN PEMBAHASAN}

Untuk mengetahui gambaran atau deskripsi suatu grup data maka dapat dilihat dari nilai ratarata, standar deviasi, maksimum, minimum, kurtosis dan kemiringan distribusi (skewness) yang disajikan dalam statistik deskriptif. Dalam penelitian ini variabel yang digunakan adalah volume ekspor, GDP, harga ekspor dan jarak ekonomi penelitian dilakukan pada 10 negara yang memiliki permintaan ekspor rumput laut terbesar. Setelah dilakukan pengujuan statistik deskriptif pada variabel tersebut maka berikut dapat dilihat hasil dari statistic deskriptifnya:

Tabel 1.

Statistik Deskripstif Penelitian

\begin{tabular}{lllll}
\hline & VE & GDP & DIST & EP \\
\hline Mean & 12781.05 & 29412.43 & 64531.48 & 11864.5 \\
Median & 13030 & 19234 & 65688.5 & 12797.5 \\
Maximum & 12726 & 23587 & 76418 & 113827 \\
Minimum & $6,246,000$ & 18519.00 & 57664.00 & 105449 \\
Std. Dev. & 2,256 & 1,849 & 4,921 & 250 \\
Skewness & $-0,155291$ & 0.383665 & 0.350273 & 0.482807 \\
Kurtosis & $2,647,317$ & $1,595,025$ & $2,568,194$ & $2,944,654$ \\
\hline
\end{tabular}

Sumber: Data Sekunder, 2021

Rata-rata volume ekspor rumput laut Indonesia ke 10 negara terbesar adalah sebesar 12.781 ton, negara-negara yang memiliki volume ekspor rumput laut di atas rata-rata adalah China sebesar 25.340 ton, Filipina sebesar 18.400 ton, Vietnam sebesar 15.678 ton, Korea sebesar 12.800 ton. Sedangkan untuk negara-negara yang memiliki volume ekspor rumput laut dibawah rata-rata adalah Chili sebesar 11.567 ton, United Kingdom sebesar 10.678 ton, USA sebesar 8.978 ton, Hongkong sebesar 5.786 ton, Jerman sebesar 3.678 ton dan Perancis sebesar 3.342 ton. GDP (Gross Domestic Product) memilik mean sebesar 20.412 USD dan negara yang memiliki GDP diatas rata-rata adalah USA memiliki GDP sebesar 65.567 USD, Jerman sebesar 46.445 USD, Hongkong sebesar 48.713 USD, Perancis sebesar 40.493 USD, United Kingdom sebesar 40.330 USD dan Korea sebesar 30.331 USD. Sementara untuk negara yang memiliki GDP dibawah rata-rata adalah China sebesar 10.261 USD, Chili sebesar 14.896 USD, Filipina sebesar 3.475 USD dan Vietnam sebesar 2.715 USD.

Dapat dilihat juga untuk rata-rata jarak ekonomi antara Indonesia dengan 10 besar negara tujuan ekspor rumput laut adalah sebesar $64.531 \mathrm{~km}$. Dimana negara dengan jarak ekonomi diatas rata-rata adalah Jerman yaitu sebesar $87.677 \mathrm{~km}$, United Kingdom sebesar $76.897 \mathrm{~km}$, Perancis sebesar $70.876 \mathrm{~km}$, Chili sebesar $65.876 \mathrm{~km}$ dan USA sebesar $65.546 \mathrm{~km}$. Beberapa negara lainya memiliki jarak ekonomi dibawah rata-rata seperti China sebesar $50.987 \mathrm{~km}$, Korea sebesar $40.765 \mathrm{~km}$,

Strategi Penetapan Bea Keluar Ekspor Rumput Laut Sebagai Upaya Optimalisasi Industri Karaginan Dalam 
Hongking $46.454 \mathrm{~km}$, Vietnam $10.437 \mathrm{~km}$ dan Filipina $8.765 \mathrm{~km}$. Dalam analisis deskriptif dapat dilihat bahwa rata-rata harga ekspor yang dimiliki 10 besar negara tujuan ekspor rumput laut Indonesia adalah sebesar 11.864 USD. Untuk negara yang memiliki harga ekspor rumput laut diatas rata-rata adalah 25.567 USD, Jerman sebesar 26.445 USD, Hongkong sebesar 28.713 USD, Perancis sebesar 20.493 USD, United Kingdom sebesar 20.330 USD dan Korea sebesar 20.331 USD. Sementara untuk negara yang memiliki GDP dibawah rata-rata adalah China sebesar 10.261 USD, Chili sebesar 4.896 USD, Filipina sebesar 3.895 USD dan Vietnam sebesar 2.915 USD.

Dari hasil estimasi model volume permintaan ekspor rumput laut Indonesia ke negara tujuan yang terdiri dari Cina, Filipina, Vietnam, Republik Korea, Cili, United Kingdom, US A, Hongkong, Jerman, dan Perancis yang diolah dengan regresi data panel menggunakan metode fixed effect dengan pembobotan dapat dilihat pengaruh antar variabel dependent dan independent.

Tabel 2.

Hasil estimasi volume permintaan ekspor rumput laut Indonesia dengan metodefixed effect dan pembobotan cross section (cross-section weighted)

\begin{tabular}{ccccc}
\hline \multicolumn{5}{c}{ Variabel Dependen LN VE } \\
\hline Variabel & Coefficient & Std. Error & T.Stat & Prob. \\
\hline LNEP & $-0,3386$ & 0,0659 & $-5,1369$ & $0,0000^{*}$ \\
LNGDP & 22,8466 & 4,9049 & 4,6579 & $0,0000^{*}$ \\
LNDIST & $-18,4694$ & 4,3962 & $-4,2013$ & $0,0001^{*}$ \\
C & $-541,2182$ & 119,1752 & $-4,2013$ & 0,0000 \\
\hline \multicolumn{5}{c}{ Weighted Statistics } \\
R-Squared & 0,9788 & Mean Depent. Var & 31,4977 \\
Adj R-Squared & 0,9728 & S. D Depent. Var & 29,1047 \\
F-Stat & 0,6948 & Sum Square Resid & 22,2033 \\
Prob (F-Stat) & 0,0000 & Durbin Wation Stat. & 1,7268 \\
\hline & \multicolumn{3}{c}{ Unweighted Statistics } \\
R-Squared & 0,8566 & \multicolumn{3}{c}{ Mean Depent. Var } \\
Sum squared resid & 34,3583 & Durbin Wation Stat. & 14,9842 \\
\hline
\end{tabular}

Keterangan : signifikan pada taraf nyata 5 persen $\left(^{*}\right)$

Sumber: Data Diolah, 2021

Dari hasil regresi model permintaan ekspor rumput laut Indonesia dapat dilihat bahwa volume ekspor rumput laut Indonesia dipengaruhi oleh beberapa variabel diantaranya variabel harga ekspor rumput laut Indonesia ke negara tujuan (LnEP), jarak ekonomi antara negara tujuan ekspor dengan Indonesia (LnDIST) serta GDP negara pengimpor rumput laut Indonesia (LnGDP).

Dari uji Hausman yang sudah dilkaukan pada peneitian ini maka diketahui nilai probabilitas yang dimiliki adalah sebesar 0,0002 yang berarti lebih kecil dari pada taraf nyata sebesar 5\%. Hal tersebut sudah cukup menjadi bukti untuk melakukan penolakan hipotesis 0 , dimana model terbaik dalam model ini menggunakan Fixed Effect Model (FEM). Model hasil pengolahan regresi data panel di atas telah memenuhi uji ekonomi karena tanda koefisien pada masing-masing variabel bebas telah sesuai dengan hipotesis berdasarkan teori ekonomi yang ada. Uji asumsi klasik pada model jug a telah terpenuhi. Nilai $\mathrm{R}^{2}$ yang tinggi dapat menyebabkan multikoliniearitas dan variabel-variabel independent pada model banyak yang tidak signifikan (Gujarati, 1994). Pembandingan nilai probabilitas dengan matrik korelasi antar variabel adalah langkah yang dilakukan untuk melakukan uji

Strategi Penetapan Bea Keluar Ekspor Rumput Laut Sebagai Upaya Optimalisasi Industri Karaginan Dalam 
multikolinearitas. Pada penelitian ini diketahui bahwa nilai $\mathrm{R}^{2}$ mencapai 0,9788 . Dari hasil analisis yang dilakukan pada model dapat dilihat ada 4 (empat) variabel bebas yang signifikan, sedangkan 1 (satu) variabel lainya tidk signifikan. Dapat disimpulkan bahwa model pada penelitian ini sudah terbebas dari multikolinearitas. Dari nilai $\mathrm{R}^{2}$ sebesar $97,88 \%$ hal ini menunjukan bahwa nilai dari GDP, jarak ekonomi dan Harga ekspor mampu menjelaskan volume permintaan ekspor rumput laut dengan data aktual sebesar $97,88 \%$ dan sisanya 2,12\% merupakan faktor yang tidak terdapat dalam model, ceteris paribus.

Dari hasil analisis yang dilakukan pada model dalam penelitian ini dapat disimpulkan tidak ada masalah heteroskedastisitas. Hal tersebut dibuktikan dengan hasil Sum Square Residual pada Weighted Statistics sebesar 22,2033 yang lebih kecil daripada Sum Squared Residual pada Unweighted Statistics sebesar 34,3583.

Model pada penelitian ini juga sudah terbebas dari masalah autokolerasi, ditunjukan dari nilai Durbin Watson sebesar 1,7268 dimana nilai tersebut telah mendekati 2,000. Hal tersebut membuktikan bahwa telah berada di wilayah nonautokolerasi dan nilai kolerasi antar variabel bebas juga tidak ada yang melebihi nilai R-squared.

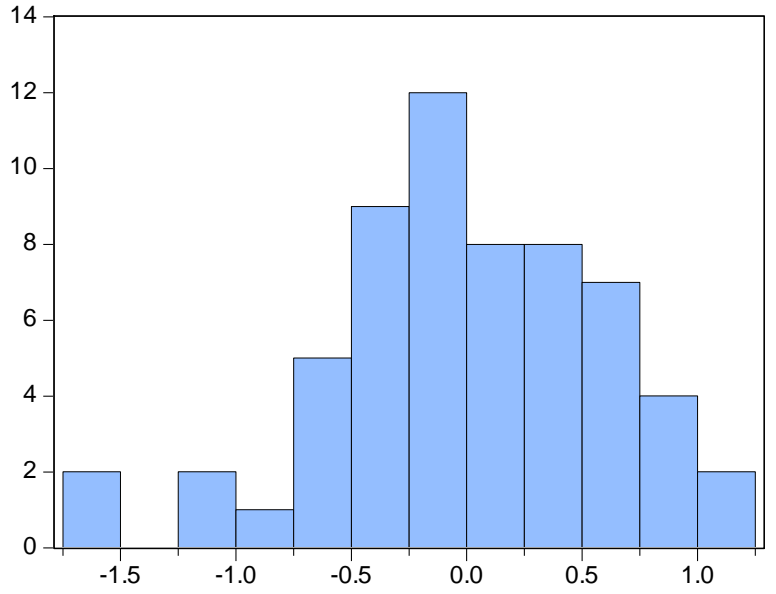

\begin{tabular}{|c|c|}
\hline $\begin{array}{l}\text { Series: Star } \\
\text { Sample } 200 \\
\text { Observatior }\end{array}$ & $\begin{array}{l}\text { ardized Res } \\
2013 \\
60\end{array}$ \\
\hline Mean & $4.38 e-16$ \\
\hline Median & -0.028343 \\
\hline Maximum & 1.233076 \\
\hline Minimum & -1.749709 \\
\hline Std. Dev. & 0.613455 \\
\hline Skewness & -0.403457 \\
\hline Kurtosis & 3.314974 \\
\hline Jarque-Ber & 1.875797 \\
\hline Probability & 0.391450 \\
\hline
\end{tabular}

Sumber: Data diolah, 2021

Gambar 3.

Hasil Uji Normalitas

Pada model volume permintaan ekspor rumput laut Indonesia memiliki error terms yang telah menyebar secara normal. Dari uji normalitas yang telah dilakukan pada panel data di model ini dapat dilihat hasil nilai Jarque-Bera sudah lebih besar dari $\alpha(1,8757>9,05)$ dan nilai probabilitas sudah lebih besar daripada $\alpha(0,392=14>0,05)$. Hal tersebut sudah memenuhi syarat dimana jika nilai Jarque-Bera lebih besar dari $\alpha$, maka model sudah menyebar secara normal.

Harga merupakan salah satu faktor yang menentukan tingkat permintaan ekspor suatu negara terhadao suatu komoditi, dimana jika harga meningkat maka permintaan akan berkurang. Hal tersebut membuat tingkat harga akan berpengaruh negatif pada permintaan ekspor suatu komoditi (Hatab \& Romstad, 2010). Dari hasil estimasi model yang menggunakan analisis data panel dapat dijelaskan bahwa variabel independent harga ekspor memiliki pengaruh negatif dan signifikan. Hal tersebut ditunjukan dari nilai probabilitas dan koefisien harga ekspor sebesar 0,0000 sudah lebih besar dari taraf nyata 5\%. Terlihat koefisien dari hasil analisis pada variabel harga ekspor adalah sebesar $-0,3386$ yang dapat diinterpretasikan bawha harga ekspor rumput laut memiliki pengaruh yang negatif terhadap volume permintaan ekspor rumput laut di Indonesia. Penurunan permintaan volume ekspor rumput

Strategi Penetapan Bea Keluar Ekspor Rumput Laut Sebagai Upaya Optimalisasi Industri Karaginan Dalam Negeri, 
laut sebesar $0,3386 \%$ disebabkan peningkatan harga ekspor rumput laut kering, hal tersebut dapat terjadi dengan asumsi variabel lain konstan. Penurunan permintaan terhadap jumlah permintaan suatu komoditi dipengaruhi dengan semakin tingginya harga yang ditetapkan. Salah satu faktor yang memengaruhi jumlah permintaan dari konsumen adalah harga (Lipsey, 1997).

Kemampuan daya beli terhadap komoditi tertentu pada suatu negara akan meningkat jika tingkat GDP negara tersebut menjadi semakin tinggi. Semakin meningkatnya GDP riill negara tujuan ekspor suatu komoditi tertentu, maka akan semakin besar pula kemampuan penyerapan produk yang diperdagangkan (Wulandari \& Budiasih, 2015). Jika suatu negara memiliki tingkat GDP yang ting gi, maka negara tujuan ekspor akan semakin meningkatkan permintaan ekspornya sehingga koefisien variabel GDP menjadi positif (Razzaghi, Ali, \& Azad, 2012). Dari hasil estimasi analisis model dalam penelitian ini GDP riil sebagai variabel independent memiliki pengaruh yang positif dan signifikan terhadap volume permintaan eskpor rumput laut kering di Indonesia. GDP riil negara tujuan memiliki probabilitas 0,0000 dengan koefisien sebesar 22,8466. Dari hasil tersebut dapat diinterpretasikan bahwa jika GDP riil negara tujuan ekspor rumput laut mengalami peningkatan sebesar 1\%, maka permintaan rumput laut akan mengalami peningkatan sebesar $22,8466 \%$ dengan asumsi ceteris paribus.

Dalam perdagangan internasional antar negara akan muncul biaya-biaya tertentu dalam prosesnya (Salvatore, 1997), salah satunya adalah biaya transportasi yang terjdi akibat adanya jarak ekonomi negara Indonesia dengan negara tujuan ekspor rumput laut kering. Peningkatan biaya disebabkan oleh jarak yang semakin jauh, sehingga akan menyebabkan makin jauhnya jarak ekonomi suatu negara maka akan menurun permintaan ekspor dari negara tersebut yang menyebabkan jarak ekonomi berpengaruh negatif (Suryana, Fariyanti, \& Rifin, 2014). Jika permintaan ekspor rumput laut kering dari Indonesia mengalami penurunan sebesar $29,6011 \%$, maka biaya transportasi anatar Indonesia dengan negara tujuan ekspor rumput laut akan mengalami peningkatan sebesar $1 \%$, ceteris paribus. Adanya biaya transportasi merupakan proksi dari hubungan negatif antara jarak perdaganagn bilateral, semakin jauh jarak suatu negara tujuan ekspor akan ikut meningkatnya biaya transportasi sehingga akan menngurangi perdangangan antar negara (Salvatore, 1997). Pada penelitian ini jarak ekonomi memiliki pengaruh negatif yang signifikan dalam model permintaan eskpor rumput laut kering di Indonesia. Diketahui nilai probabilitas jarak ekonomi sebesar 0,0000 signifikan pada taraf nyata 5\%. Koefisien dari jarak ekonomi sebesar -18,4694 dapat diinterpretasikan jika jarak ekonomi memiliki hubungan yang negatif dengan volume permintaan ekspor rumput laut kering di Indonesia.

Salah satu upaya ang dapat diterapkan negara untuk mengurangi tingkat ekspor rumput laut ke negara tujuan, sehingga bahan baku industri dalam negeri dapat terpenuhi adalah dengan dikenakanya Bea Keluar ekspor bahan baku rumput laut. Untuk menghitung Bea Keluar yang dapat dikenakan untuk komoditi bahan baku rumput laut, digunakan data rata-rata total ekspor ke negara China sebagai negara utama tujuan ekspor. China merupakan negara tujuan ekspor yang menguasai 59 persen permintaan ekspor rumput laut dari tahun 2015 sampai dengan 2019, yaitu dengan rata-rata total ekspor sebesar 89212 ton. Setelah itu digunakan data rata-rata harga dunia dari tahun 2015 hingga 2019 untuk komoditi bahan baku rumput laut sebesar US \$ 975 yang memiliki elastisitas sebesar 0.33 . Untuk dapat menurunkan kapasitas menganggur industri karaginan, dibutuhkan penambahan bahan baku rumput laut sebesar 5404 ton, maka perhitungan Bea Keluar rumput laut sebagai upaya mengurangi volume ekspor rumput laut ke negara tujuan digunakan analisis elastisitas harga sebagai berikut:

$$
\varepsilon=\partial \mathrm{Q} / \partial \mathrm{P} . \mathrm{P} / \mathrm{Q}
$$

Strategi Penetapan Bea Keluar Ekspor Rumput Laut Sebagai Upaya Optimalisasi Industri Karaginan Dalam 
Dari perhitungan yang menggunakan analisis elastisitas harga, maka diketahui besar Bea keluar yang dapat dikenakan untuk bahan baku rumput laut yaitu hingga 18 persen. Dengan penetapan Bea Keluar hingga 18 persen akan menyebabkan harga bahan baku rumput laut meningkat di pasar internasional. Adanya peningkatan harga akibat pengenaan Bea Keluar ekspor bahan baku rumput laut kering sebesar 18 persen diharapkan dapat mengurangi volume ekspor bahan baku rumput laut ke negara tujuan ekspor. Berkurangnya volume ekspor dapat menambah bahan baku rumput laut untuk industri pengolahan rumput laut dalam negeri terutama industri pengolahan karaginan (Kanaya \& Firdaus, 2014). Diharapkan dengan penambahan bahan baku industri karaginan dapat lebih mengoptimalkan produksinya untuk dapat memenuhi permintaan karaginan di dalam negeri, sehingg a industri-industri yang menjadikan karaginan sebagai input produksinya tidak perlu lagi mengimpor karaginan dari luar negeri.

Adanya Bea Keluar rumput laut diharapkan harga bahan baku rumput laut dapat terjadi peningkatan ditingkat petani. Dengan adanya peningkatan harga bahan baku rumput laut kering yang mengurangi tingkat ekspor negara tujuan akan berdampak pada meningkatkan ketersediaan bahan baku untuk industri pengolahan domestic (Yuniarti, 2007). Ketika bahan baku industri pengolahan rumput laut dalam negeri terpenuhi bahan bakunya, maka produksi Semi Refined carrageenan dan Refined Carrageenan juga akan ikut meningkat. Sehingga Indonesia dapat melakukan ekspor dari produk-produk rumput laut yang sudah memiliki nilai tambah di pasar internasional. Pengenaan Bea Keluar untuk ekspor rumput laut kering dalam jangka pendek akan membuat harga ekspor menjadi lebih tinggi di pasa internasional dan berdampak pada turunya permintaan ekspor (Mankiw, 2007). Dengan begitu akan terjadi kelebihan penawaran pada bahan baku rumput laut di dalam negeri. Pengembangan industri pengolahan dalam negeri akan semakin berkembang dengan melimpahnya sumber bahan baku domestik dalam jangka panjang. Tidak hanya itu, dengan keuntungan yang didapat pemerintah dari penetapan Bea Keluar pemerintah dapat menyelenggarakan pelatihan-pelatihan untuk petani rumput laut. Pelatihan tersebut merupakan salah satu kompensasi yang diberikan pemerintah untuk mengganti kerugian sementara petani rumput laut, akibat penetapan Bea Keluar bahan baku rumput laut. Dengan adanya pelatihan tersebut, petani akan mampu memproduksi rumput laut yang lebih berkualitas dan memiliki daya saing di pasar internasional dengan harga yang relatif tinggi (Zainol Arifin, 2013).

\section{SIMPULAN DAN SARAN}

Permintaan ekspor rumput laut kering mengalami peningkatan ekspor mulai dari tahun 2015 sampai dengan 2019. Harga ekspor rumput laut, GDP riil negara tujuan ekspor dan jarak ekonomi antara Indonesia dengan negara importir rumput laut merupakan faktor-faktor yang memegaruhi volume permintaan ekspor ke sepuluh besar negara tujuan yaitu Cina, Filipina, Vietnam, Republik Korea, Cili, United Kingdom, USA, Hongkong, Jerman dan Perancis. Dari hasil penelitian yang dilakukan menggunakan data panel dengan gravity model pada periode waktu 2015 - 2019, maka diketahui bahwa harga ekspor dan jarak ekonomi berpengaruh negatif dan signifikan terhadap volu me ekspor rumput laut, sementara GDP riil memiliki pengaruh positif dan signifikan terhadap volume permintaan rumput laut. Sebagai upaya untuk memenuhi kebutuhan bahan baku industri pengolahan karaginan, maka perlu diberlakukanya bea keluar pada ekspor rumput laut kering. Dari hasil analisis elastisitas harga diketahui bahwa dengan pengenaan Bea Keluar rumput laut sebesar 18\% akan secara efektif dapat menurunkan permintaan ekspor rumput laut.

Strategi Penetapan Bea Keluar Ekspor Rumput Laut Sebagai Upaya Optimalisasi Industri Karaginan Dalam 
Dalam upaya untuk memenuhi kebutuhan bahan baku industri pengolahan rumput laut dalam negeri, dibutuhkan kebijakan pembatasan ekspor rumput laut kering tanpa nilai tambah. Dimana pada penelitian ini diketahui bahwa untuk dapat mengurangi ekspor rumput laut secara efektif dapat dtetapkan bea keluar sebesar 18\%. Selain kebijakan untuk mengurangi ekspor rumput laut kering, dibutuhkan program system kemitraan dan penyuluhan kepada para petani rumput laut untuk dapat meningkatkan kualitas budidaya dan menambahkan nilai tambah pada hasil produksi rumput laut. Sementara untuk pelaku industri pengolahan rumput laut dibutuhkan program pendampingan mulai dari awal proses hingga proses pemasaran produk untuk mengoptimalisasikan kualitas ouput rumput laut olahan yang dapat bersaing di pasar internasional.

\section{REFERENSI}

A. MuhammadYushan Patawari, \& Nyoman Suarsana. (2019). Peningkatan EkonomiPetani Ru mput Laut Di Desa Ta muku Kecamatan Bone-Bone Kabupaten Luwu Utara. Jurnal Ekonomi Pembangunan, 7(2), 156 162.

Denantica, D. P. (2012). Ana lisis Faktor-Faktor yang Mempengaruhi Ekspor Rumput La ut. Jurnal Ekonomi Pertanian, Volume 13(3), 54-80.

Efendi, B. (2017). Analisis Daya Saing Peningkatan Ekspor Rumput Laut Indone sia. Jurnal Manajemen \& Agribisnis, 2(2), 1-7.

Eni Kusumawati. (2019). Analisis Faktor Determinan Suplai Ekspor CPOProvinsi Jambi. Jurnal So sial Dan Humaniora Universitas Muhammadiyah Bandung, 1(2), 70-92.

Fa isa l, \& Akmal Huda Na sution. (2015). Dampak Kebijakan Pajak Ekspor Terhadap Perdagangan Minyak Sawit Indonesia. Jurnal Ekonomi Pertanian, Volume 13(2), 1-13.

FAO. (2018). The Global Status of Seaweed Production, Trade and Utilization. Retrieved Ju ne 1, 202 1, from http://www.fao.org/in-action/globefish/publications/details-publication/en/c/1154074/

Farhanah Wahyu. (2011). Analisis Hubungan Tingkat Produksi Dengan Tingkat Pendapatan Petani Rumput Laut di Desa Punaga Kecamatan Mangararombang Ka bupaten Talakar. Jurnal Ekonomi Pembangunan, Volume 13(2009), 732-741.

Gujarati. (1994). Ekonometrika Dasar. (Hutauruk Gunawan, Ed.) (2nd Editio). Jakarta:Erlangga.

Hatab, \& Romstad. (2010). Determinants of Egyptian Agricultural Exports: A Gravity Model Approach. Modem Economy, 1 (1):, 134-143. Retrieved from http://www.scirp.org/journal/

Hikmah. (2021). Strategi Pengembangan Industri Pengolahan Ko moditas Rumput La ut E. Cotonii Untuk Peningkatan Nilai Tambah di Kawasan Industrialisasi. Jurnal Agribisnis, Volume 54(February). https://doi.org/10.15578/jksekp.v5i1.1013

Ika Fatmawati, \& Didik Wahyudi.(2015). Potensi Rumput Laut di Kabupaten Su menep. Jurnal Agribisnis, $12(2), 1-9$.

Indria ni dan Sumiarsih. (1999). Budidaya, Pengolahan, dan Pemasaran Rumput Laut. (Hety Indriani, Ed.). Jakarta: Penebar Swa daya.

Kanaya, \& Firda us. (2014). Permintaan Ekspor Produk Biofarmaka Indonesia di Negara Tujuan UtamaPeriode 2003-2012. Jurnal Manajemen \& Agribisnis, 11 (3), 183-198.

Kha ldun, R. I. (2017). Strategi Kebijakan Peningkatan Daya Saing Rumput Laut Indone sia di Pa sar Global. Jurnal Ekonomi Pembangunan, 3(1), 99-125.

KKP. (2021). Produksi Rumput Laut Indonesia. Retrieved June 15, 2021, from https://kkp.go.id/

Lestari Agusalim. (2014). Pajak Ekspor, Pertumbuhan Ekonomi dan Pendapatan: Kasus Agro industri di Indonesia. Jurnal Ekonomi Dan Manajemen, 18(2), 180-194.

Lipsey. (1997). Pengantar Makroekonomi (Jilid 2). Jakarta: Binarupa Aksara.

Mankiw. (2007). Teori Makroekonomi. (Sa at Suryadi, Ed.) (Edisi Keli). Jakarta: Erlangga.

Ma swadi. (2012). Da mpak Penerapan Ekspor Crude Palm Oil Terha dap Kinerja Agribisnis Kela pa Sa wit dan Penda patan Petani Indonesia. Jurnal Ekonomi Pembangunan, 1(April), 1-14.

Rachman, B., \& Adang Agustian. (2015). PajakEkspor dan Pengaruhnya Terh adap CPO Indonesia. Jurnal Ekonomi Pertanian, Volume 14(2), 103-112.

Razzaghi, Ali, \& Azad. (2012). Determinants of Trade Flows between D-8 Group Members through Gravity Model. Journal Basic and Applied Scientific Research, Vol 2 (6), 5726-2731. Retrieved from http://textroad.com/pdf/JBASR/J. Basic. Appl. Sci. Res., 2(6)5726-5731, 2012.pdf\%0A

Salvatore. (1997). Ekonomi Internasional. (Sumiharti, Ed.) (5th Editio). Ja karta: Erlangga.

Strategi Penetapan Bea Keluar Ekspor Rumput Laut Sebagai Upaya Optimalisasi Industri Karaginan Dalam 
Satar, M., \& Kurnia Nurhakim. (2015). Prosedur Pelaksanaan Kegia tan Ekspor Barang. Jurnal Manajemen \& Agribisnis, 5(2), 16-21.

Shepherd. (2013). The GravityModel of InternationalTrade: A User Guide.Cambridge: ambridge Univ ersity Press. https://doi.org/10.1017/CBO9780511762109

Sudiarta. (2017). Kawasan Minapolitan ( Studi Kasus di Kawasan Minapolitan Desa Labuhan Kertasari Kabupaten Sumbawa Barat, Nusa Tenggara Barat ). Jurnal Manajemen \& Agribisnis, 5(2), 45-50.

Suka pto, P., \& Bagus Made Arthaya. (2014). Pemberdayaan Usa ha Kecil RumputLaut Aulia Sari di Kelu ra han Majahlega, Kecamatan Rancasari, Bandung. Jurnal Ekonomi Pembangunan, Volume 5(2), 56-65.

Surya na, Fa riyanti, \& Rifin. (2014). Analisis Perdagangan Kakao Indonesia di Pa sar Interna sional. Jurnal Tanaman Industri Dan Penyegar, Vol 1 (1):, 29-40. Retrieved from http://ejurnal.litbang.pertanian.go.id/index.php/bultri/article/view/2321/2014

Wulandari, \& Budiasih. (2015). Faktor-faktor yang Memengaruhi Total Perdagangan Bilateral. Jurnal Manajemen \& Agribisnis, Vol. 12(2), 131-146. Retrieved from http://journal.ipb.ac.id/index.

Yuniarti. (2007). Perdagangan Bilateral Indonesia Pendekatan Gravity Model. [Jurnal] Jurnal Ekonomi Pembangunan. Jurnal Ekonomi Pembangunan, 9-109. Retrieved from journal.uii.ac.id/index.php/JEP/article/download/509/421

Za inol Arifin. (2013). Budidaya Rumput Laut Dan Pengembangan Usaha Dalam Meningkatkan Potensi Wilayah Pesisir Selatan Pa mekasan. Jurnal Agribisnis, Volume 6(1), 1-15. 